\title{
First record of Colletotrichum sansevieriae on Sansevieria sp. (mother-in-law's tongue) in Australia
}

\author{
R. Aldaoud • S. DeAlwis • S. Salib • J. H. Cunnington • \\ S. Doughty
}

Received: 10 November 2010 / Accepted: 18 May 2011 /Published online: 29 July 2011

(C) Australasian Plant Pathology Society Inc. 2011

\begin{abstract}
Colletotrichum sansevieriae was detected for the first time on nursery-grown plants of mother-in-law's tongue (Sansevieria sp.) in Australia.
\end{abstract}

\section{Keywords Mother-in-law's tongue $\cdot$ Colletotrichum} sansevieriae

\section{Introduction}

Colletotrichum sansevieriae was previously reported to cause anthracnose disease on Sansevieria plants in Japan (Nakamura et al. 2006). Infected plants develop large lesions on affected leaves, that eventually coalesce to cover a large proportion of affected leaves, and affected plants are virtually unmarketable. However this disease has not been known to occur in Australia before. In October 2008, a sample of Sansevieria plants from Victoria, Australia, was sent to Crop Health Services at the Department of Primary Industries for diagnosis of pathogens associated with a problem of leaf lesions (Fig. 1). A Colletotrichum fungus was detected on the leaf lesions by direct microscopy. Fungal isolation from $0.5 \% \mathrm{NaOCl}$-surface-sterilised lesions, undertaken on tetracycline-amended potato dextrose agar (PDAT), consistently recovered the same fungus (Fig. 2).

R. Aldaoud $(\bowtie) \cdot$ S. DeAlwis $\cdot$ S. Salib $\cdot$ J. H. Cunnington $\cdot$

S. Doughty

Biosciences Research Division, Department of Primary Industries,

Knoxfield, Private Bag 15, Ferntree Gully delivery Centre,

Melbourne, VIC 3156, Australia

e-mail: ramez.aldaoud@dpi.vic.gov.au
To confirm the identification the ribosomal DNA internal transcribed spacer region was amplified and sequencing using primers ITS5 and ITS4 (White et al. 1990). The sequence was identical to the authentic rDNA ITS2 $C$. sansevieriae sequences on GenBank (accessions AB212990 and AB212991). The sequence from the Australian isolate has been deposited on GenBank as accession HQ433226. The culture of $C$. sansevieriae has been deposited in the DPI Plant Pathology Herbarium as accession VPRI 41498.

Pathogenicity testing was undertaken on detached leaves. Leaves were pricked in 3 locations, about $2 \mathrm{~cm}$ apart, using a sterile needle, and were placed on pads of sterile, moist tissues in take-away plastic containers. The pricked leaf areas were inoculated by mounting with $0.5 \mathrm{~cm}$ dia. agar plugs, excised from 2-week-old PDAT cultures of $C$. sansevieriae, with fungal mycelia and acervuli facing down. This experiment was performed in 3 replicates, with 2 detached leaves in each container. Upon inoculation, containers were tightly closed with their plastic tops and each placed in a ziplock plastic bag. Blank agar plugs were placed on the leaves used as un-inoculated control. Containers were kept in the laboratory under constant fluorescent light for $24 \mathrm{~h}$, with temperature ranging from $17-22^{\circ} \mathrm{C}$. Leaves were observed for symptom development at weekly intervals, over 3 weeks. One week after inoculation, plants started to develop necrotic lesions and rot, radiating from the inoculated areas (Fig. 3), similar to those observed on the submitted sample. Symptoms become progressively more severe in time, as lesions coalesced and covered most of the leaf surface within 
Fig. 1 Leaf lesions from natural infection

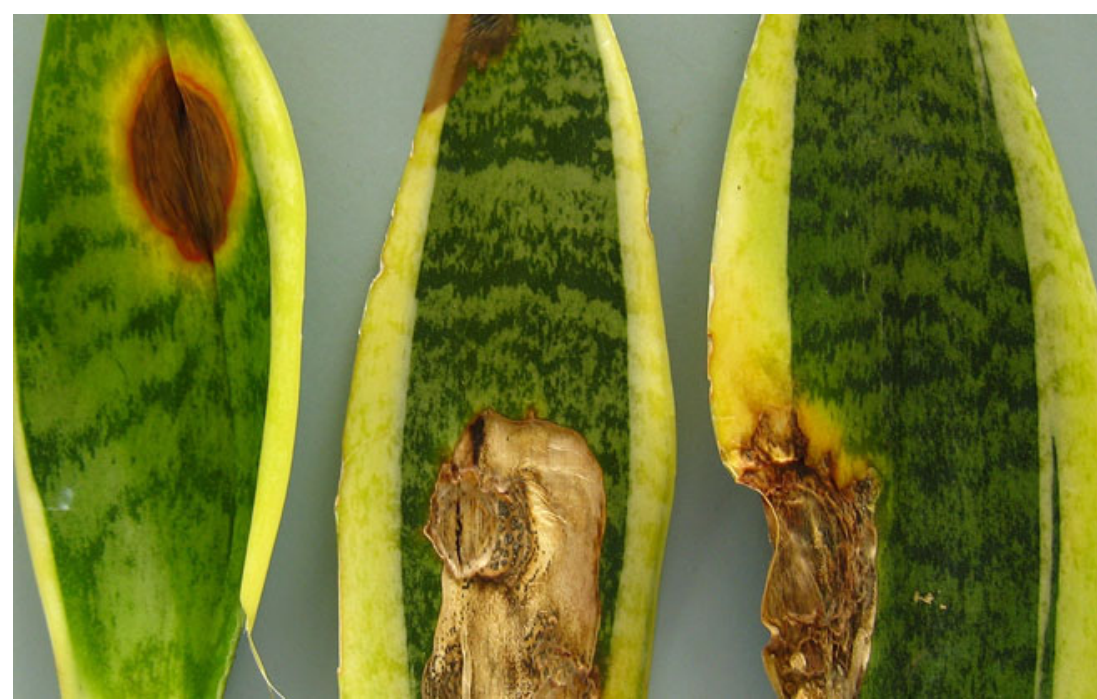

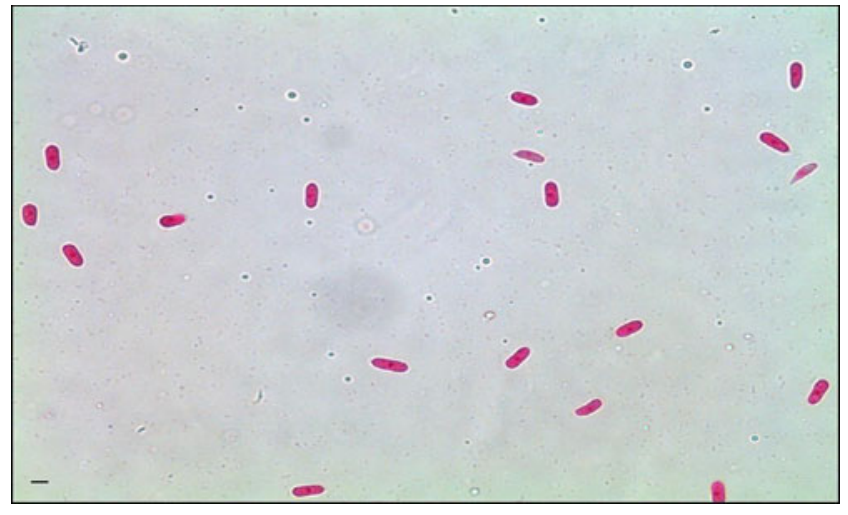

Fig. 2 Conidia of the Colletotrichum fungus detected; bar $=10 \mu \mathrm{m}$

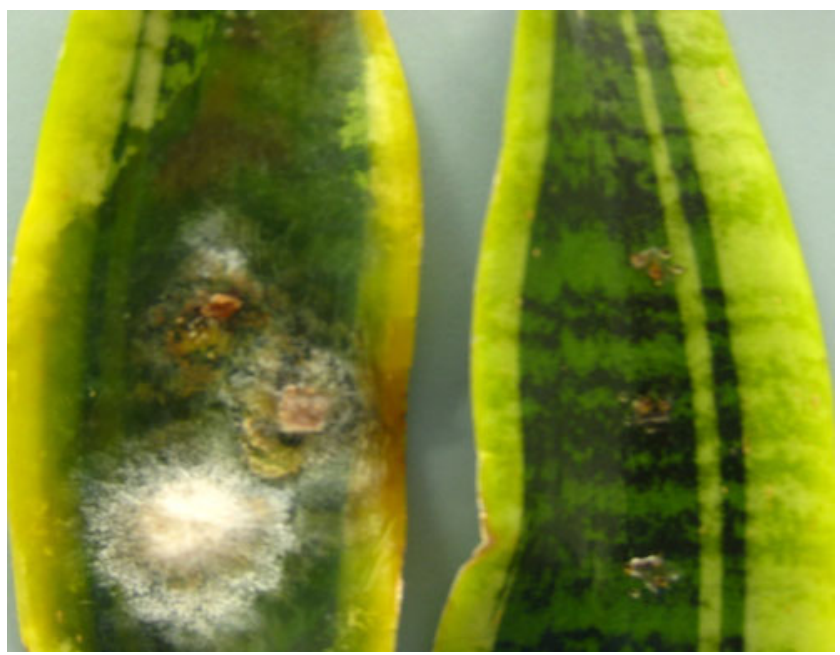

Fig. 3 Leaf lesions from artificial inoculation: left, inoculated leaf; right, uninoculated control
3 weeks. Microscopic examination of the leaf lesions consistently detected $C$. sansevieriae, and this was confirmed further by fungal isolation on PDAT medium, thus fulfilling Koch's postulates.

To our knowledge this is the first record of this fungus in Australia. Infection by $C$. sansevieriae has implications especially for nurseries and the marketability of Sansevieria plants if left unchecked. This is in addition to its potential effect on both intra- and interstate movement of plant material. It is, however, fortunate that $C$. sansevieriae is restricted to Sansevieria plants, and therefore it poses no risk to other non-related plants.

\section{References}

Nakamura M, Ohzono M, Iwai H, Arai K (2006) Anthracnose of Sansevieria trifasciata caused by Colletotrichum sansevieriae sp. nov. J Gen Plant Pathol 72:253-256

White TJ, Bruns TD, Lee S, Taylor JW (1990) Amplification and direct sequencing of fungal ribosomal RNA genes for phylogenetics. In 'PCR Protocols: a guide to methods and applications'. (Eds MA Innis, DH Gelfand, JJSninsky and TJ White) pp 315322 